\title{
PEMANFAATAN IOT (INTERNET OF THINGS) PADA IRIGASI TETES UNTUK TANAMAN JERUK
}

\author{
Mila Kusumawardani ${ }^{1}$, Moechammad Sarosa ${ }^{1}$, Ratih Indri Hapsari ${ }^{2}$ \\ ${ }^{1}$ Jurusan Teknik Elektro \\ ${ }^{2}$ Jurusan Teknik Sipil \\ Politeknik Negeri Malang \\ mila.kusumawardani@polinema.ac.id, msarosa@polinema.ac.id, ratihindri@gmail.com
}

\begin{abstract}
Abstrak
Tanaman jeruk manis (Citrus $X$ sinensis) merupakan salah satu produk unggulan Desa Petungsewu Kabupaten Malang. Selama ini, Mitra mengandalkan air hujan dengan menggunakan sistem tadah hujan untuk mengairi tanamannya. Persoalan muncul tatkala musim kemarau, terbatasnya air menjadi kendala utama saat Mitra ingin melakukan penyiraman maupun penyemprotan. Akibat terbatasnya air, tanaman hanya mampu berbuah sekali dalam setahun tidak seperti tanaman di perkebunan lain yang mendapatkan irigasi air sungai yang mampu berbuah dua kali dalam setahun. Untuk mengatasi terbatasnya air, maka diusulkan suatu tandon air dengan ukuran 4x6x2 $\mathrm{m}^{3}$ sebagai tempat penyimpanan air dari sistem tadah hujan, sedangkan untuk mengendalikan penggunaan air saat melakukan penyiraman digunakan sistem irigasi tetes yang dikendalikan menggunakan teknologi Internet of Things (IoT). Selain menyediakan tandon air, pada kegiatan ini juga dibangun suatu surau di atas tandon dan toilet. Karena ketidak tersediaan sumber energi listrik, maka kegiatan ini juga menyediakan sumber energi terbarukan berupa energi panel surya. Sistem penyiraman dilakukan secara otomatis menggunakan sensor kelembaban tanah, jika kelembaban kurang dari 70\% maka valve akan membuka sehingga air mengalir, sebaliknya jika kelembaban telah terpenuhi maka valve akan menutup. Adanya kegiatan ini, Mitra dapat melakukan penyiraman tanaman secara otomatis meskipun di musim kemarau, dan tanaman jeruk bisa berbuah dua kali dalam setahun.
\end{abstract}

Kata Kunci : tanaman jeruk, irigasi tetes, tandon air, Internet of Things.

\begin{abstract}
Citrus $X$ sinensis plants are one of the main products of Petungsewu Village, Malang Regency. So far, partners (citrus farmers) have relied on rainwater by using rainfed systems to irrigate their crops. Problems arise during dry season because limited water making watering or spraying become difficult. As a result plants are only able to produce fruits once a year while the same plants in other lands with good irrigation can produce fruits twice. To overcome the problem of limited water, it is determined to have a $4 \times 6 \times 2 \mathrm{~m} 3$ water reservoir as an water storage area for rainfed systems. While to control water usage when watering uses a cliff system using the Internet of Things (IoT) technology. In addition, to provide water storage, this activity also built a shelter on the reservoir and toilets. Because of the unavailability of electrical energy sources, this activity also provides renewable energy sources that contain solar panel energy. The watering system is carried out automatically using a soil moisture sensor if the humidity is less than 70\%, so that the valve will open and the water flows. On the other hand, if the humidity is greater or equal to $70 \%$, the valve will be closed. With the existence of this activity, partners can do automatic watering of plants during dry season, and citrus plants can produce fruits twice in a year.
\end{abstract}

Keywords : Citrus $X$ sinensis plants, drip irrigation, reservoir, Internet of Things 


\section{PENDAHULUAN}

Balai Penelitian Tanaman Jeruk dan Buah Subtropika (Balitjestro) melalui lamannya pada tahun 2015, menginformasikan bahwa salah satu sentra perkebunan jeruk Indonesia berada di wilayah Kecamatan Dau Kabupaten Malang. Salah satu varian jeruk yang dikembangkan adalah jeruk manis dengan kebutuhan air untuk tanaman jeruk diperkirakan sebanyak 50 liter air/m2 lahan setiap bulan (Tamba, 2014). Secara struktur tanah di daerah tersebut didominasi oleh tekstur debu dengan komposisi rata-rata $56,33 \%$, pasir $23,67 \%$, dan liat $20 \%$ (Susanawati, 2018).

Mitra merupakan petani jeruk di Desa Petungsewu Kecamatan Dau yang memiliki permasalahan dalam hal penyediaan air untuk irigasi kebun. Pada saat curah hujan tinggi (musim penghujan) mitra menampung air hujan dalam kontainer/kolam tadah hujan yang terbuat dari terpal. Kesulitan akan muncul pada musim kemarau karena kolam menjadi kering. Solusi yang dilakukan oleh mitra adalah melakukan pengambilan air dari sungai terdekat yang berada di bagian bawah lereng dengan menggunakan pompa air dan kemudian menyiramkan ke kebun jeruk secara manual. Dengan kontur tanah yang tidak datar dan luasan kebun yang tidak sedikit, ditambah dengan jumlah personil yang kurang memadai menjadikan pengairan kebun sebagai suatu permasalahan yang dihadapi oleh mitra. Kendala lain berhubungan dengan teknik penyiraman yang dilakukan secara manual. Semua pohon mendapat pengairan dalam jumlah yang sama, sedangkan ditinjau dari posisi tanah sangat memungkinkan kebutuhan tiap pohon berbeda sebagai akibat dari kelembaban tanah yang tidak sama.

Kegiatan ini bertujuan untuk memberikan altermatif solusi bagi mitra dalam mengatasi masalahnya. Solusi yang ditawarkan adalah pembangunan suatu tandon penyimpan air dengan dimensi $(4 \times 6 \times 2 m)$ yang dilengkapi dengan sistem irigasi tetes berbasis IoT (Internet of things). Sistem irigasi ini dipantau melalui sensor kelembaban dan sensor $\mathrm{pH}$ serta kamera sehingga kondisi terkini dari kebun dapat diketahui.Sistem dilengkapi dengan program aplikasi yang akan memberikan fasilitas tambahan misalnya bagi pemilik kebun yang tidak selalu berada di lokasi untuk mendapatkan informasi tentang irigasi.

Penelitian penunjang kegiatan ini dilakukan oleh D. A. Sati, D. K. Malikarjuna and D. P. K. Dutta (2017), yang melakukan perancangan sistem irigasi secara otomatis dengan menggunakan sirkuit elektronik untuk mendeteksi kelembaban dan memanfaatkan energi matahari sebagai sumber daya listrik.Informasi status pompa diberikan kepada petani dalam format SMS (Short Message Service). Penelitian mengenai monitoring proses irigasi tetes menggunakan Internet of Things(IoT) dilakukan oleh R. Chidambaram RM dan V. Upadhyaya (2017). Sistem ini menggunakan sensor kelembaban tanah untuk mengetahui nilai kelembaban tanah secara real time yang selanjutnya disimpan di database untuk menganalisis kebutuhan air tanaman kemudian ditampilkan pada smartphone. Kamera juga digunakan dalam sistem ini tapi hanya untuk menunjukkan hasil deteksi warna tanaman yaitu hijau atau merah.

Pustaka utama yang menunjang diantaranya adalah teori mengenai irigasi tetes, IoT, sensor (kelembaban tanah dan $\mathrm{pH}$ ), Maximum Power Point Tracker (MPPT), dan Android Studio. Irigasi tetes merupakan irigasi yang menggunakan jaringan aliran dengan memanfaatkan gaya gravitasi. IoT memiliki gagasan untuk mengkomunikasikan antar perangkat sebagai bagian dari satu kesatuan sistem terpadu menggunakan jaringan internet sebagai penghubung. Sensor kelembaban tanah yang digunakan adalah YL-69 yang terdiri atas 1 buah elemen pendeteksi kelembaban, 1 modul pemroses sinyal, dan 1 set kabel koneksi. Sensor $\mathrm{pH}$ tanah menjadi sensor pendeteksi tingkat keasaman (acid) atau kebasaan (alkali) tanah dengan skala 3.5 hingga 8. Sensor ini dapat langsung disambungkan dengan pin analog arduino maupun pin analog mikrokontroler lainnya. MPPT merupakan metode yang digunakan pada controler charger yang biasanya digunakan pada pembangkit tenaga angin dan solar cell yang berfungsi untuk memaksimalkan daya keluaran bagi

Teknologi Informasi dan Komunikasi 
sistem tersebut. Android Studio menyediakan kerangka kerja memungkinkan untuk membangun aplikasi bagi perangkat seluler di lingkungan bahasa pemrograman Java.

\section{METODE}

Secara keseluruhan pelaksanaan kegiatan ini dapat dibagi menjadi 4 tahapan yaitu pembuatan sistem irigasi tetes berbasis IoT yang disertai dengan sensor kelembaban tanah, pembangunan tandon air, pembuatan surau di atas tandon, serta pelaksanaan sosialisasi.

Pembuatan sistem irigasi tetes diawali dengan perhitungan estimasi kebutuhan pipa, kran, dan sensor kelembaban serta kebutuhan material lain (Kholifah, 2019). Variabel yang berpengaruh adalah data ketersediaan air, banyaknya pohon dan luas efektif lahan perkebunan. Dilakukan juga analisis hidrolika, analisis hidrologi, dan perhitungan struktur reservoir (Faustha, 2019). Selanjutnya dilakukan perencanaan teknis atas komponen penyusun sistem irigasi tetes (Udiana, 2014) yaitu sumber air, panel surya, accu, MPPT, modul IoT, sensor kelembaban tanah, pompa dan tenaga penggerak, serta jaringan perpipaan. Perencanaan irigasi ditunjukkan dalam Gambar 1. Instalasi sistem ini baru dapat dilaksanakan setelah bangunan tandon selesai dikerjakan. Sambil menunggu kesiapan bangunan, penelitian dan uji coba sistem irigasi dilaksanakan dalam skala laboratorium. Dalam hal ini mitra berkontribusi pada penyediaan pompa air.

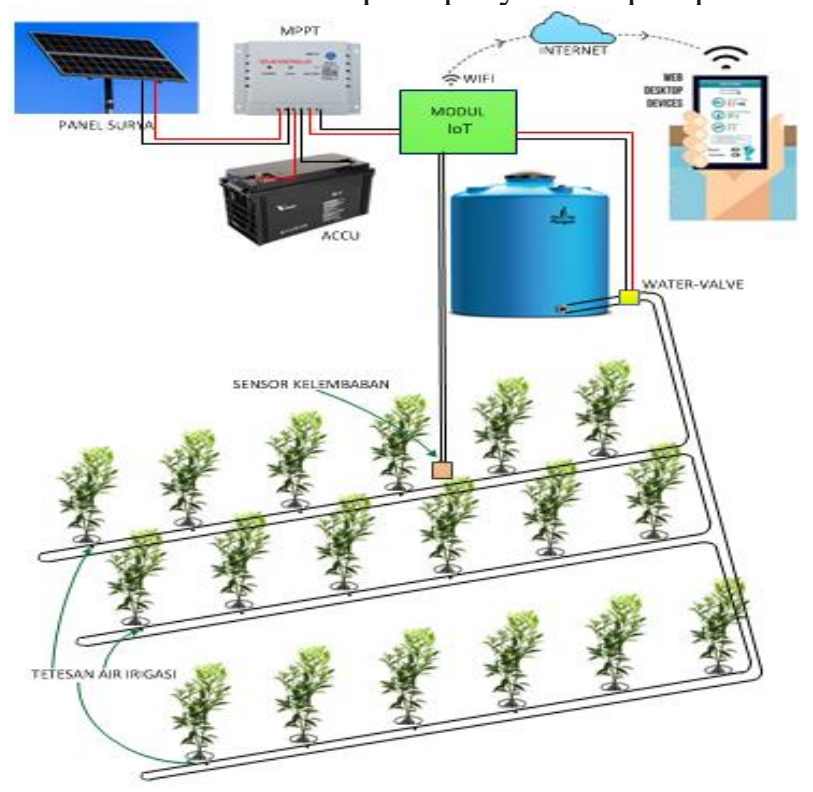

Gambar 1. Perencanaan irigasi tetes berbasis IoT

Persiapan pembangunan tandon diawali dengan studi lapangan, pengukuran elevasi tanah, perkiraan lokasi bangunan/tandon, dan penentuan titik pengambilan air di sungai. Dilanjutkan dengan perencanaan teknis yang meliputi perencanaan bentuk, bahan, dan dimensi tandon. Hasil perencanaan bangunan tandon ditunjukkan pada Gambar 2. Selanjutnya adalah pelaksanaan konstruksi yang merupakan pelaksanaan pembangunan tandon dan pemasangan pipa serta pompa air. Setelah konstruksi selesai dilaksanakan berikut sistem pemipaannya maka dilakukan pengecekan untuk mengetahui kesiapan sistem. Jika pengecekan menunjukkan hasil baik maka tandon siap untuk diisi dengan air sungai. Melalui uji coba, sistem diperkenalkan dengan kondisi kerja sebenarnya. Dalam hal ini sekaligus dapat diketahui juga kinerja dari sub sistem yang ada misalnya pompa air.
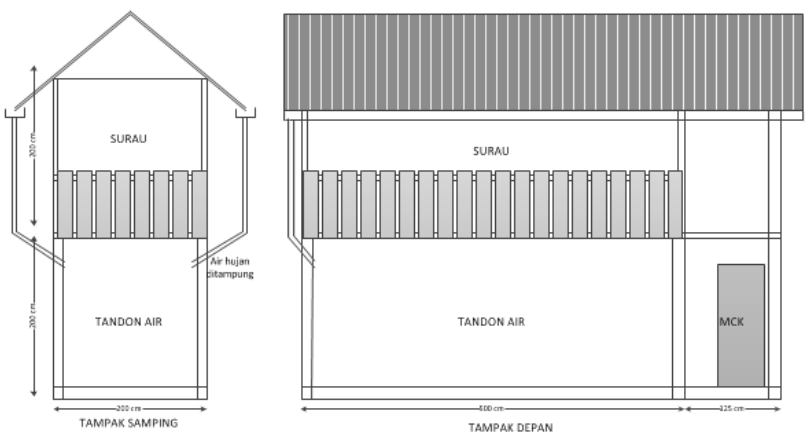

Gambar 2. Layout bangunan (tandon air, surau, dan MCK)

Dari gambar 2 diketahui bahwa secara fungsional, bangunan terdiri dari 3 bagian yaitu tandon air sebagai bagian utama, dan surau serta MCK sebagai fasilitas lain. Surau ditempatkan di atas tandon air dengan dimensi yang sama dengan bangunan tandon. Bangunan di atas tandon ini sebenarnya multifungsi, tidak hanya digunakan sebagai surau tapi bisa juga untuk keperluan lain misalnya pertemuan anggota kelompok tani mitra.

Setelah proses pembangunan selesai secara menyeluruh selanjutnya dilaksanakan sosialisasi kepada mitra mengenai cara kerja dan pemeliharaan sistem irigasi tetes serta fungsionalitas bangunan. Disampaikan pula tentang prosedur pengisian air di

Teknologi Informasi dan Komunikasi 
tandon sehingga dengan adanya sosialisasi diharapkan mitra mendapatkan manfaat maksimal dari sistem yang ada.

\section{HASIL DAN PEMBAHASAN}

Kegiatan ini dilaksanakan mulai bulan Mei 2019, diawali dengan kunjungan ke lokasi pada 4 Mei 2019. Melalui kunjungan ini diperoleh gambaran riil mengenai kondisi lahan dan tanaman jeruk. Bersama dengan mitra, tim mendiskusikan titik lokasi yang akan digali sebagai bangunan tandon, ukuran tanah galian serta kedalamannya (gambar 3). Dilanjutkan dengan diskusi tentang sistem irigasi tetes (10-11 Mei 2019) yang sesuai dengan kebutuhan mitra. Diperoleh informasi bahwa jumlah tanaman jeruk yang memerlukan irigasi adalah 650 pohon.

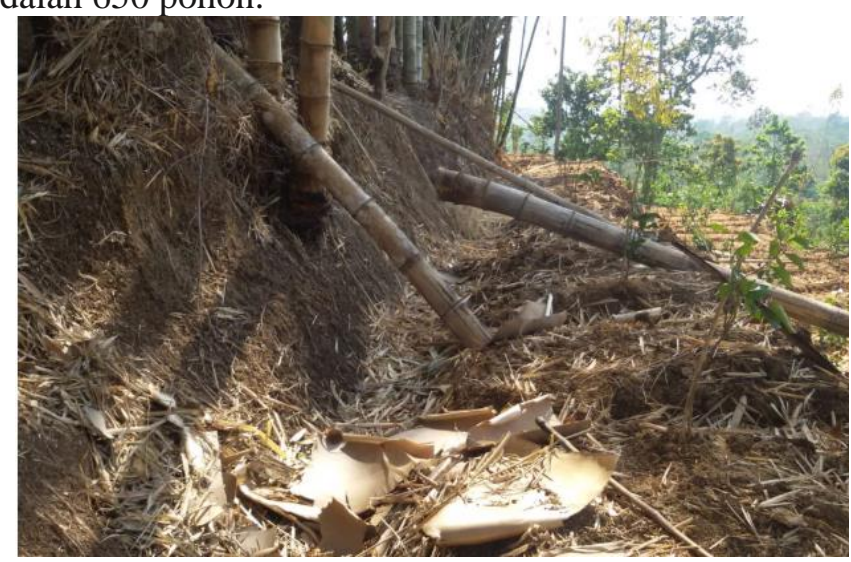

Gambar 3. Rencana lokasi bangunan tandon

Dari diskusi yang dilakukan dibuat rencana teknis sistem irigasi dan pengadaan material untuk irigasi, yang dilanjutkan dengan pengembangan sistem. Sistem akan melakukan irigasi berdasarkan hasil pembacaan sensor kelembaban tanah. Jika tanah terdeteksi kering maka panel surya akan mengaktifkan sistem irigasi dengan mengambil air dari tandon. Sistem irigasi yang telah selesai dikembangan diuji coba di Polinema. Pengujian meliputi uji keakuratan pembacaan sensor kelembaban dan $\mathrm{pH}$ tanah, pengujian tegangan dan arus dari panel surya dan batrei, serta uji keakuratan kamera.

Di lokasi (kebun mitra) dilakukan penggalian tanah sejak tanggal 17 Juni 2019 untuk bangunan tandon dengan dimensi $4 \mathrm{~m} \times 6 \mathrm{~m}$ dengan kedalaman $1 \mathrm{~m}$ (bagian tandon yang tertanam di tanah), ditunjukkan dalam gambar 4. Tanah yang telah digali harus dipindahkan posisinya dari area kebun menuju luar kebun sehingga tidak mengganggu proses selanjutnya (pembangunan tandon dan instalasi sistem irigasi tetes). Setelah lahan untuk bangunan dalam kondisi siap untuk digarap maka perlu pembelanjaan material bangunan. Posisi lahan yang tidak di tepi jalan raya mengakibatkan diperlukannya pengangkutan material bangunan dari jalan raya menuju kebun.

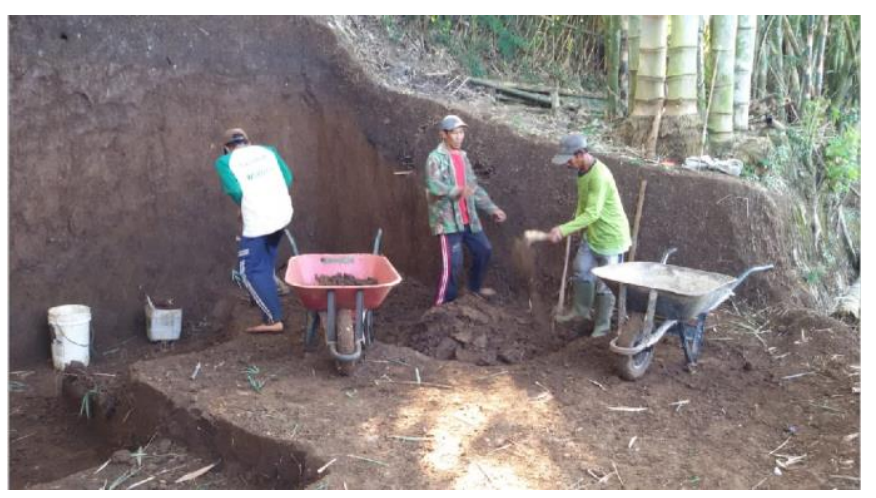

Gambar 4. Penggalian tanah untuk bangunan tandon

Material telah disiapkan, lahan siap untuk dibangun. Tahapan selanjutnya adalah pembangunan tandon air. Bagian atas tandon air merupakan ruangan fungsional yang dapat dijadikan surau. Bangunan dilengkapi dengan toilet sebagai fasilitas MCK.

Hasil kegiatan ini akan dipublikasikan melalui Konferensi Nasional PkM-CSR yang dilaksanakan di Surabaya pada bulan Oktober 2019. Kegiatan ini merupakan kerjasama dari 3 perguruan tinggi. Sebagai persiapan dari konferensi sebelumnya perlu dilakukan penyusunan dan upload artikel. Luaran tertulis yang lain untuk mempermudah penyampaian informasi kepada mitra adalah berupa buku panduan, ditunjukkan dalam gambar 5. Melalui buku ini mitra akan lebih mudah mendapatkan referensi mengenai pengoperasian dan perawatan sistem irigasi tetes.

Setelah secara teknis sistem irigasi diuji coba di Polinema (gambar 6), selanjutnya sistem diuji coba di lokasi sebenarnya yaitu kebun mitra (gambar 7). Pengujian yang sama kembali dilakukan untuk

Teknologi Informasi dan Komunikasi 
mengetahui konerja sistem sebelum dilakukan instalasi.

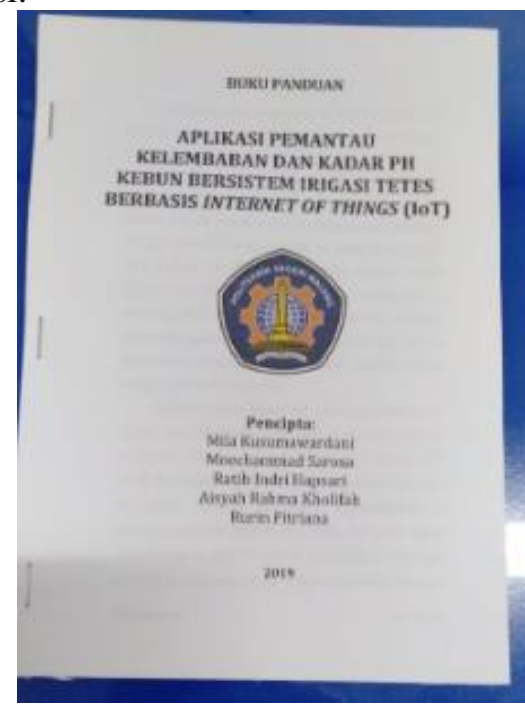

Gambar 5. Buku panduan

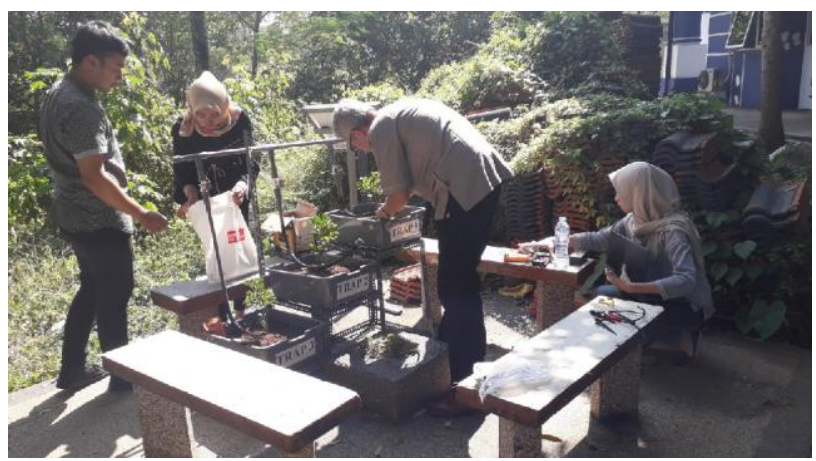

Gambar 6. Uji coba irigasi tetes di Polinema

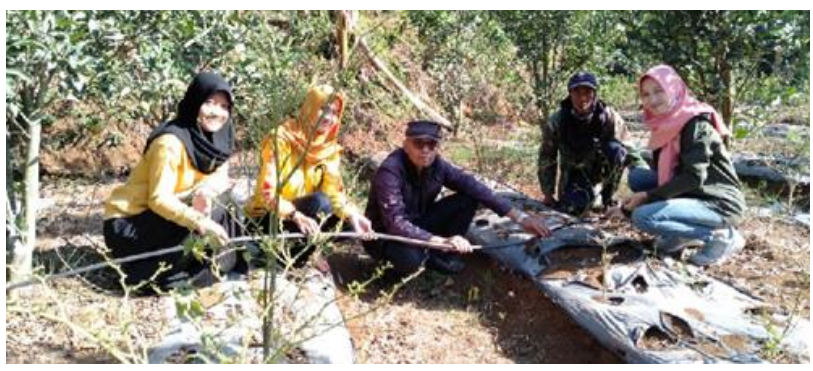

Gambar 7. Uji coba irigasi tetes di kebun mitra

\section{KESIMPULAN}

Kesimpulan yang diperoleh adalah 1) sistem irigasi tetes berbasis IoT yang disertai dengan sensor kelembaban tanah telah dapat berfungsi; 2) bangunan tandon dan surau sedang dalam proses pengerjaan; 3) kendala yang dihadapi di lapangan adalah sumber daya manusia, dalam hal ini adalah pekerjaan bangunan yang tidak dapat dilaksanakan selama bulan Ramadhan.

\section{UCAPAN TERIMAKASIH}

Ucapan terimakasih disampaikan kepada Direktorat Riset dan Pengabdian kepada Masyarakat yang telah memberikan kontribusi dalam pelaksanaan kegiatan, berupa pendaaan melalui skema Pengabdian Kepada Masyarakat Kompetitif Nasional.

\section{REFERENSI}

D.A Sati, D.K Malikarjuna. D.P.K Dutta. (2017). Sensor Based Solar Tracker System UsingElectronic Circuit for Moisture Detectionand Autu-Irrigation. IEEE International Conference on Power, Control, Signal, and Instrumentation Engineering, p 1475

Faustha, Deo Pramudika. (2019). Perencanaan Irigasi tetes di Desa Petungsewu. Tugas Akhir. Politeknik Negeri Malang

Fitriana, N., Arianti, FD., Sepipermas, MN. 2014. Irigasi tetes : Solusi Kekurangan Air pada Musim Kemarau. Balai Pengkajian Teknologi Pertanian Jawa Tengah

Kholifah, AR. dan Fitriana, R. (2019). Sistem Irigasi Tetes Berbasis IoT (Internet of Things) Menggunakan Energi Panel Surya. Tugas Akhir. Politeknik Negeri Malang

Masudia, PE., Sarosa, M., Gatot, AY., Afriana, P., Rakhmania, AE. (2018)., Developiong a Weather Monitoring System on Android Platform. International Jornal of Computer Application, Volume 182 Number 23, pp 22-26

R.Chindambaram RM., V.Upadhyaya. (2017). Automatic In Drip Irrigation using IoT Devices. Fourth Internasional Conference on Image Information Procesing (ICIIP) Journal IEEE. P.323

Sugiyatno, Agus. 2015. Melihat Potensi Bukit Jeruk di Malang. Balai Penelitian Tanaman Jeruk dan Buah Subtropika.Departemen Pertanian

Teknologi Informasi dan Komunikasi 
Susanawati, LD., dan Suharto, B. (2018). Kebutuhan Air Tanaman untuk Penjadwalan Irigasi pada Tanaman Jeruk Keprok 55 di Desa Selorejo Menggunakan Cropwat 8.0. Jurnal Irigasi

Tamba, Mariati. (2014). Pengairan dan Pengeringan Tanaman Jeruk. Badan Penyuluhan dan Pengembangan Sumber Daya Manusia Pertanian. Departemen Pertanian
Udiana, IM., Bunganaen, W., Padja, RAP. (2014). Perencanaan Sistem Irigasi Tetes di Desa Besmarak Kabupaten Kupang. Jurnal Teknik Sipil Vol iii No.1 